\title{
Quality Evaluation of Enzyme Liquefied Papaya Juice Concentrate (PJC) Stored at Various Temperatures
}

\author{
B. V. Vishal, A. S. Chauhan", M. N. Rekha, P. S. Negi \\ Department of Fruit and Vegetable Technology, CSIR-Central Food Technological Research Institute, Mysore, India
}

Email address:

attar2010@yahoo.com (A. S. Chauhan)

To cite this article:

B. V. Vishal, A. S. Chauhan, M. N. Rekha, P. S. Negi. Quality Evaluation of Enzyme Liquefied Papaya Juice Concentrate (PJC) Stored at Various Temperatures. Journal of Food and Nutrition Sciences. Vol. 3, No. 3, 2015, pp. 90-97. doi: 10.11648/j.jfns.20150303.12

\begin{abstract}
This paper aims to study the effect of storage on enzyme liquefied papaya juice concentrate. Papaya pulp was liquefied using pectinase enzyme for juice extraction. The enzyme liquefied juice was subjected to concentration process by adopting Single Effect Tubular Evaporator (SETE) at $50^{\circ} \mathrm{C}$ with 24 inches vacuum. The Papaya Juice Concentrate (PJC), $68^{\circ} \mathrm{brix}$ was packed in high density polyethylene (HDPE) jars (200 g capacity) by leaving one inch head space and packed PJC jars were stored at various temperatures such as room temperature (RT, $29 \pm 1{ }^{\circ} \mathrm{C}$ ), low temperature (LT, $4^{\circ} \mathrm{C}$ ) and frozen storage temperature $\left(\mathrm{FT},-18^{\circ} \mathrm{C}\right)$. The PJC samples were analyzed for physicochemical characteristics and microbial load at 15 days intervals using methods reported in the literature. During storage, the PJC samples stored at RT showed significant increase in L, $a$ and $b$ values and browning as compared to LT and FT, while slight change in carotenoid content was observed. At the end of one month storage, the microbial counts (colony-forming unit/g) like total plate counts, yeast and molds counts and Staphylococcus counts in the PJC samples were low and Escherichia coli was absent. The study showed that enzymatic liquefaction can be used for better juice extraction from papaya and PJC prepared from this juice was physicochemically and microbiologically stable at various temperatures for one month.
\end{abstract}

Keywords: Enzyme Liquefaction, Concentrate, Temperature, Quality Evaluation, Papaya Juice

\section{Introduction}

Papaya (Carica papaya L.) belongs to the caricaceae family. It is commonly known as papaw or papita. Papaya is native of tropical America, and has become a very popular fruit worldwide due to its fast growth, high yield, long fruiting period and high nutritive value. Raw papaya is usually consumed for vegetable purpose and also for papain production. The ripe papaya is utilized more for direct consumption rather than harnessing its potential for diversified product development. There is an increasing demand for papaya juice as ingredients for blended juices, concentrates, syrups, juice drinks and soft drinks. However, due to its chemical nature (rich in pectin, starch and fiber), the clarification process becomes difficult [1], [2], [3]. In order to degrade pectin, pectinolytic enzyme treatment is carried out on the raw pulp. These enzymes cause protein pectin complexes to flocculate resulting in juice of low pectin complexes and low viscosity [4], which is advantageous for subsequent filtration processes, besides yielding a significant increase in extraction of juice from raw material.
Production of juices and concentrates is difficult from fruits and vegetables due to their viscous nature of pulps/purees [5]. Maceration enzymes are used to facilitate smooth juice extraction. During liquefaction, cell walls are degraded leading to the release of cell contents and other enzyme like ß-glucosidase helps in fruit aroma liberation [6]. The pectic enzymes, generally regarded as safe are widely used to reduce viscosity; ease juice extraction, liquefaction and clarification; increase yield and clarity, release pigments and total phenols. The enzyme clarified lime (Citrus aurantifolia L.) juice concentrate was prepared and subjected to evaluation of its rheological behaviour by [7] at different temperatures $\left(20-80^{\circ} \mathrm{C}\right)$. The Litchi (Litchi chinensis) juice was produced from viscous pulp by using optimized concentration of pectinase [8]. Changes in quality attributes of juice concentrates obtained by enzyme liquefaction of galgal (Citrus pseudolimon; hill lemons) juice followed by concentration during storage were studied by [9]. Potential for developing acceptable procedures for processing cantaloupe 
into clarified juice and juice concentrate was investigated by [10] and authenticity of fruit juice concentrates was studied earlier by [11]. The immature Date palm (Phoenix dactylifera) juice, concentrate and storage studies of date juice concentrate for a period of 6 months were carried out by [12].

Fruit juices and purees have high amount of water and they are difficult to preserve. Fruit juice concentration process is very useful to increase the solid content in the range of $65-75 \%$. The concentrated fruit juices are microbiologically stable and needs less storage space due to reduction in bulk density. Hence, it is not only beneficial but also economical to the consumer for end product packaging, transportation and distribution [13], [14], [15]. The microbiology of fruit juice concentrates is greatly influenced by their reduced water activity [16].

Therefore, an attempt was made to develop enzyme liquefied papaya juice. Enzyme liquefied juice requires more packaging materials and also adequate storage spaces. Attempts were made to increase its solid content to more than $65 \%$ without changing its liquid form with reduction in bulk density. The objectives of the research work were to optimize the process conditions for the preparation of enzyme liquefied papaya juice and preparation of high solid content fruit juice concentrate from enzyme liquefied juice. Further, the physicochemical and microbial changes in papaya juice concentrate stored at room temperature (RT, $29 \pm 1^{\circ} \mathrm{C}$ ), low temperature $\left(\mathrm{LT}, 4^{\circ} \mathrm{C}\right)$, and frozen storage temperature (FT, $-18^{\circ} \mathrm{C}$ ) were studied.

\section{Materials and Methods}

\subsection{Materials}

The ripe papaya fruits (Red Indian variety) were purchased from the local market of Mysore city, brought to the Department of Fruit and Vegetable Technology at CSIR-Central Food Technological Research Institute, Mysore, Karnataka, India. The high density polyethylene (HDPE) container (200 g capacity) was used for packaging the fruit juice concentrate and subsequent storage at RT, LT and FT. The commercial pectinolytic enzyme (Biotropicase) obtained from the Novozyme Pvt Ltd, Bangalore, India, was used for the enzymatic liquefaction of papaya pulp. Microbiological media and sterilized plates were purchased from Himedia (Mumbai, India).

\subsection{Papaya Pulp Preparation}

Ripe papaya fruits (48 kgs) were subjected to washing, peeling, deseeding and cutting into small pieces using a stainless steel knife. The pieces of papaya were crushed in a fruit mill and pulper (B. Sen and Berry, New Delhi, India) to get fine pulp $(25.86 \mathrm{~kg})$.

\subsection{Optimization of Process Conditions for the Enzymatic Liquefaction of Papaya Pulp}

The general flow chart for the preparation of enzyme (Biotropicase) liquefied papaya juice and concentrate is illustrated in Fig. 1. For optimized process conditions, papaya pulp $(25.86 \mathrm{Kg})$ was homogenized by heating up to $45^{\circ} \mathrm{C}$ and the enzyme $(1.25 \%)$ was added to the fine pulp. The sample was kept for incubation at RT $\left(29 \pm 1^{\circ} \mathrm{C}\right)$ for 2 hours. Later the enzyme treated papaya pulp was heated for $5 \mathrm{~min}$ at $70^{\circ} \mathrm{C}$ in order to inactivate the enzyme. After cooling, the juice was filtered through muslin cloth and the juice yield was noted (20.72 1). The preservative (potassium metabisulfite, $0.05 \%$ w/w) was added to the enzyme liquefied papaya juice. Juice (3 1) was taken out for preliminary analysis and the rest part of juice was subjected to Single Effect Tubular Evaporator (SETE) under vacuum (24 inches) for 40 minutes to obtain high degree brix papaya juice concentrate $\left(68^{\circ} \mathrm{brix}\right)$. The concentrate obtained was filled into a pre-sterilized HDPE jars (200 g each) and stored at three different temperatures (RT, LT and FT) for one month. The physicochemical changes and microbial stability of the product during storage were analysed at 15 days intervals.

\subsection{Quality Evaluation of Fresh Papaya Pulp, Enzyme Liquefied Juice and Stored Juice Concentrate at Varying Temperatures}

Physicochemical properties of the samples such as color $(\mathrm{L}=$ lightness, $\mathrm{a}=+$ redness/-greenness, $\mathrm{b}=+$ yellowness /-blueness and $\Delta \mathrm{E}=$ color difference), total soluble solids ( ${ }^{\circ}$ brix), $\mathrm{pH}$, acidity, non-enzymatic browning (NEB), total carotenes, ascorbic acid, reducing sugar, total invert sugar and total sugar were determined as per standard procedures described by [17]. The viscosity of the sample was measured using a digital viscometer (model no. R 1:3M, Rheological Int.). The spindle number 3 was connected to the digital viscometer and its rotation was fixed at $100 \mathrm{rpm}$ for 30 seconds. The viscosity of the sample was expressed as mPas.

\subsection{Microbial Analysis}

Homogenous mixture was prepared by mixing $25 \mathrm{~g}$ of the sample (papaya juice concentrate) and $225 \mathrm{ml}$ saline. The samples were further diluted serially in saline (if needed) and plated for total plate count, yeasts and mould count and Staphylococcus aureus count; and detection of Escherichia coli by pour plate method [18] using plate count agar, potato dextrose agar, Baird-Parker agar and Macconkey agar, respectively. The presence or absence of typical E. coli colonies was recorded for Macconkey agar and for other agars colonies were counted and the count was expressed as cfu/g.

\subsection{Storage of the PJC at Various Temperatures (RT, $4^{\circ} \mathrm{C}$ and $-18^{\circ} \mathrm{C}$ )}

The storage of the PJC was carried out at three different temperatures viz. room temperature (RT, $29 \pm 1^{\circ} \mathrm{C}$ ), low temperature $\left(\mathrm{LT}, 4^{\circ} \mathrm{C}\right)$ and frozen storage temperature (FT, $-18^{\circ} \mathrm{C}$ ) for a period of 30 days. The withdrawal of the PJC samples was carried out at 15 days intervals and the samples were subjected to physicochemical and microbial evaluations. 


\subsection{Statistical Analysis}

The means of all the parameters were examined for significant difference by analysis of variance (ANOVA). The means were compared by $t$-tests for physicochemical characteristics of fresh papaya pulp and enzyme liquefied papaya juice; and PJ (after inactivation of enzyme) and PJC. During storage, all the means were compared by Tukey-Kramer Multiple Comparisons Test. Significance was determined at $p \leq 0.05$.

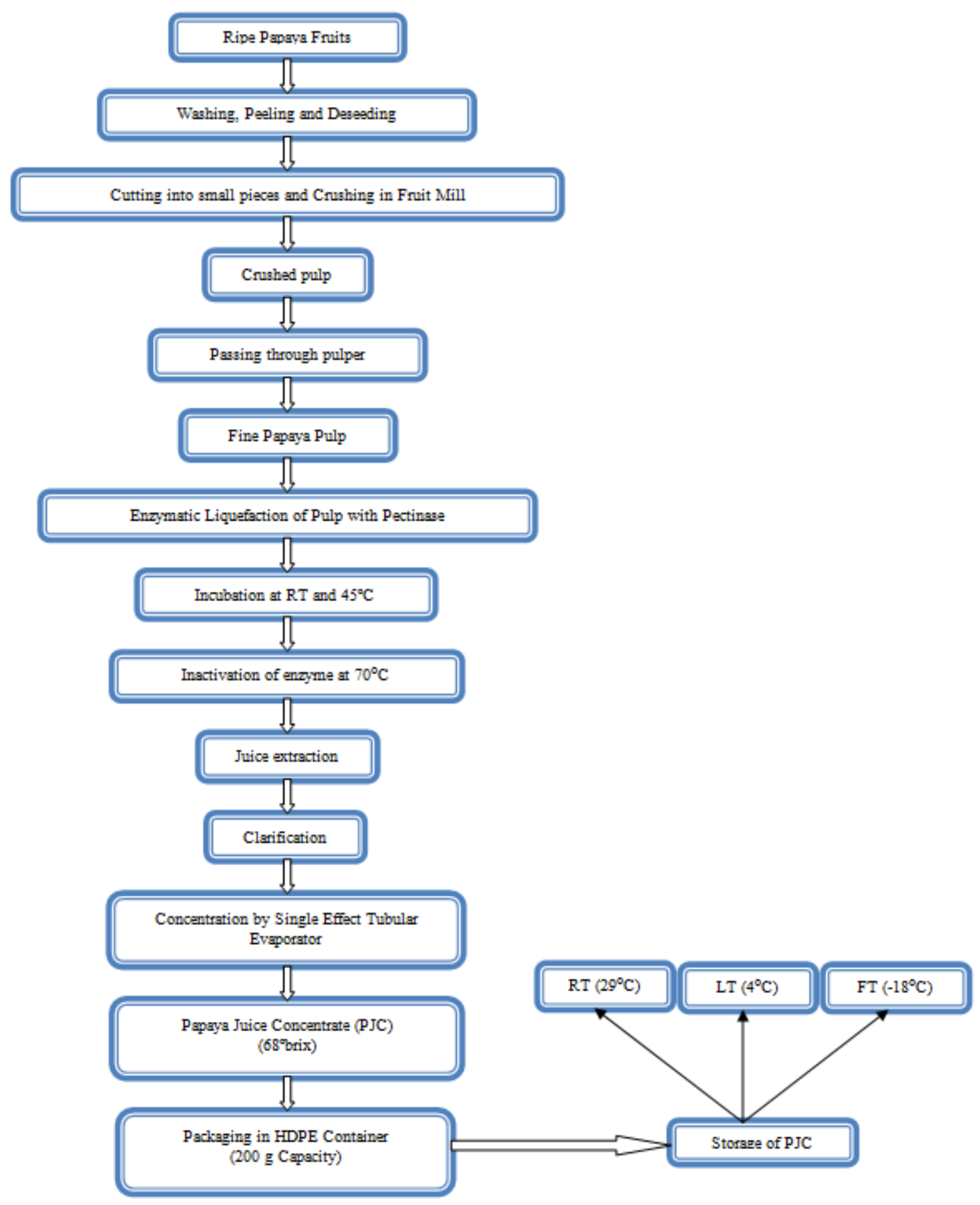

Figure 1. Flow Chart for the preparation of enzyme liquefied papaya juice and concentrate (PJC).

\section{Results and Discussion}

\subsection{Standardization of Papaya Juice Yield}

For optimization of enzyme liquefaction, papaya pulp was treated with varying concentrations of the enzyme $(0.25-2.0 \%)$ for the incubation time of 2 hours at two different temperatures (RT and $45^{\circ} \mathrm{C}$ ). It was observed that RT condition, and $1.25 \%$ enzyme concentration showed better results and hence was used for scale up process.

The physicochemical characteristics of both, the fresh papaya pulp as well as enzyme liquefied papaya juice were 
observed (significantly different at $\mathrm{p} \leq 0.05$ ). It was noticed that the fresh papaya pulp $(1801.43 \mu \mathrm{g} / 100 \mathrm{~g})$ and enzyme liquefied papaya juice $(1650.39 \mu \mathrm{g} / 100 \mathrm{~g})$ were good source of total carotenoids (Table 1). Significant variations were observed in TSS, ascorbic acid and acidity in both fresh pulp and enzyme liquefied juice, the $\mathrm{pH}$ and total carotenoids were lower in enzyme liquefied juice as compared to fresh pulp.

Table 1. Physiochemical characteristics of the fresh papaya pulp and juice.

\begin{tabular}{lll}
\hline Parameters & Fresh Papaya pulp & Enzyme liquefied papaya juice \\
\hline $\mathrm{pH}$ & $5.75 \pm 0.01$ & $4.75 \pm 0.02$ \\
Total Soluble Solids ( ${ }^{\circ}$ brix) & $11.61 \pm 0.01$ & $11.89 \pm 0.01$ \\
Acidity (as\% anhydrous citric acid) & $0.336 \pm 0.00$ & $0.368 \pm 0.00$ \\
Ascorbic acid $(\mathrm{mg} / 100 \mathrm{~g})$ & $14.56 \pm 0.01$ & $14.25 \pm 0.01$ \\
Total Carotenoids $(\mu \mathrm{g} / 100 \mathrm{~g})$ & $1801.43 \pm 0.58$ & $1650.39 \pm 0.63$ \\
\hline
\end{tabular}

Mean $\pm \mathrm{SD}(\mathrm{n}=3)$; $t$-test shows that all parameters were significantly different at $\mathrm{p} \leq 0.05$.

\subsection{Scale up Studies on the Enzymatic Liquefaction of Papaya and Preparation of PJC}

Large scale preparation of papaya juice as illustrated in Fig. 1 was done at the optimum conditions using $48 \mathrm{~kg}$ papaya fruits. After peeling, deseeding and cutting into medium sized pieces the weight of papaya was found to be $32.9 \mathrm{~kg}$. The chopped pieces of papaya were then crushed in a fruit mill and pulped in a pulper and $25.86 \mathrm{~kg}$ pulp was obtained. The pulp was treated with pectinase enzyme $(1.25 \%)$ and then incubated in a kettle at RT for 2 hours. After completion of the incubation period, the enzyme was inactivated by employing heat treatment $\left(70^{\circ} \mathrm{C}\right.$ for 5 minutes $)$. The pulp was allowed to cool at room temperature and filtered using muslin cloth. The total juice yield was found to be $20.72 \mathrm{~kg}$. To this enzyme liquefied papaya juice, $0.05 \%$ KMS was added. The initial brix of the fresh papaya was found to be $11.61^{\circ}$ brix (Table 1) whereas $12.2^{\circ}$ brix was observed for enzyme liquefied papaya juice after inactivation of enzyme (Table 2 ).
A SETE was employed for the preparation of high degree brix juice concentrate. Enzyme liquefied papaya juice $(17.7 \mathrm{~kg})$ was fed to the vacuum evaporator for concentration process. The inlet steam pressure was adjusted to be 24 inches vacuum, and the temperature was kept at $55^{\circ} \mathrm{C}$ with $1 \mathrm{Kg} / \mathrm{cm}^{2}$ pressure. The yield of $2.04 \mathrm{~kg}(11.53 \%)$ of PJC was obtained with 68 ${ }^{o}$ brix.

The physiochemical characteristics of enzyme liquefied papaya juice (PJ) and concentrate (PJC) were compared (significantly different at $\mathrm{p} \leq 0.05$ ). The total invert sugars, total sugars and reducing sugars were much higher in the concentrate as compared to enzyme liquefied juice. The color was enhanced in the PJC due to increase in total carotenoids $(11365.94 \mu \mathrm{g} / 100 \mathrm{~g})$ pigments and also it was found more acidic due to enhancement in acidity (as \% anhydrous citric acid, 1.76\%) and ascorbic acid (12.90 mg/100 g) content as compared to the enzyme liquefied papaya juice $(0.374 \%$ acidity and $9.672 \mathrm{mg} / 100 \mathrm{~g}$ ascorbic acid) (Table 2).

Table 2. Physiochemical Properties of Juice and Concentrate.

\begin{tabular}{lll}
\hline Parameters & Papaya Juice (PJ) (After inactivation of enzyme) & Papaya Juice Concentrate (PJC) \\
\hline Total Solid Sugars ( ${ }^{\circ}$ brix) & $12.20 \pm 0.01$ & $68.08 \pm 0.07$ \\
pH & $4.70 \pm 0.01$ & $4.52 \pm 0.01$ \\
Acidity (as \% anhydrous citric acid) & $0.374 \pm 0.00$ & $1.76 \pm 0.01$ \\
Non-enzymatic browning (OD at 440 $\mathrm{nm}$ ) & $0.048 \pm 0.00$ & $0.231 \pm 0.00$ \\
Reducing sugars (\%) & $6.737 \pm 0.00$ & $50.71 \pm 0.01$ \\
Total invert sugars (\%) & $8.21 \pm 0.01$ & $56.70 \pm 0.01$ \\
Total sugars (\%) & $10.71 \pm 0.00$ & $67.05 \pm 0.10$ \\
Ascorbic acid $(\mathrm{mg} / 100 \mathrm{~g})$ & $9.672 \pm 0.00$ & $12.90 \pm 0.01$ \\
Total carotenoid $(\mu \mathrm{g} / 100 \mathrm{~g})$ & $1650.93 \pm 1.10$ & $11365.94 \pm 0.21$ \\
Viscosity $(\mathrm{mPaS})$ & $12.70 \pm 0.01$ & $1066 \pm 1.00$ \\
\hline
\end{tabular}

\pm SD of Mean values $(\mathrm{n}=3)$; $t$-test shows that all parameters were significantly different at $\mathrm{p} \leq 0.05$.

\subsection{Quality of PJC During Storage}

\subsubsection{Effect on Color (L a b* Values) and Non-Enzymatic Browning (NEB)}

The color of PJC was significantly affected by the storage temperatures (Table 3 ) (significantly different at $\mathrm{p} \leq 0.05$ ). The color values of the PJ and PJC were significantly different from each other. Initial analysis (0 day) showed a significant decrease in $\mathrm{L}^{*}$ and $\mathrm{b}^{*}$ values whereas significant increase in $\mathrm{a}^{*}$ and $\Delta \mathrm{E}$ values was observed in PJC samples as compared to the enzyme liquefied papaya juice (PJ). Storage of PJC at varying temperatures for 15 days resulted in significant increase in the L a b* values of PJC samples stored at RT when compared to FT and LT. The PJC samples stored at RT again showed increase in the $\mathrm{L} \mathrm{a} \mathrm{b*}$ values after $30^{\text {th }}$ day storage also as compared to LT and FT stored PJC samples. The increase in $\mathrm{L} \mathrm{a} \mathrm{b*} \mathrm{values} \mathrm{can} \mathrm{be} \mathrm{attributed} \mathrm{to} \mathrm{the} \mathrm{fact} \mathrm{that} \mathrm{PJC} \mathrm{was}$ progressing towards browning due to increase in sugar content, titrable acidity and loss of ascorbic acid.

The results of changes in NEB of PJC with respect to varying storage temperatures are presented in Table 4 . The RT stored PJC samples showed gradual increase in the NEB values $\left(0.223,0.468 \& 0.515\right.$ during storage for $0^{\text {th }}, 15^{\text {th }} \& 30^{\text {th }}$ days, respectively) as the storage duration progresses and it 
was higher as compared to LT $(0.223,0.248 \& 0.266$ during storage for $0^{\text {th }}, 15^{\text {th }} \& 30^{\text {th }}$ days, respectively) \& FT $(0.223$, $0.242 \& 0.261$ during storage for $0^{\text {th }}, 15^{\text {th }} \& 30^{\text {th }}$ days, respectively) stored PJC samples. It might be due to the influence of storage temperatures on the reducing sugar of PJC. NEB occurs in the food products due to the reaction between an amino acid and a reducing sugar. The sugar interacts with the amino acid, producing a variety of odors and flavors. The reducing sugars can interact with amino acids and form dark color via Maillard reaction [19], [20]. Storage temperature has a great influence on browning of PJC and its storage at FT \& LT leads to minimal browning and minimal loss of color in comparison with the samples stored at RT. It has also been reported that the fruit juice concentrate undergoes excessive browning during storage at ambient temperature [21], [22].

Table 3. Effect of storage temperatures on the color intensity of papaya juice concentrate (PJC).

\begin{tabular}{|c|c|c|c|c|c|c|}
\hline \multirow{2}{*}{ Storage (days) } & \multirow{2}{*}{ Sample } & \multirow{2}{*}{ Storage Temperatures } & \multicolumn{4}{|l|}{ Color values } \\
\hline & & & $\mathbf{L}$ & $\mathbf{a}$ & b & $\Delta \mathbf{E}$ \\
\hline \multirow[t]{2}{*}{0} & PJC & -- & $18.59 \pm 0.02^{\mathrm{a}}$ & $25.30 \pm 0.01^{\mathrm{a}}$ & $12.29 \pm 0.02^{\mathrm{a}}$ & $77.66 \pm 0.01^{\mathrm{a}}$ \\
\hline & & RT & $13.05 \pm 0.05^{\mathrm{b}}$ & $12.82 \pm 0.00^{\mathrm{b}}$ & $18.03 \pm 0.02^{\mathrm{b}}$ & $78.59 \pm 0.01^{\mathrm{b}}$ \\
\hline \multirow[t]{3}{*}{15} & PJC & $\mathrm{LT}$ & $12.18 \pm 0.01^{\mathrm{c}}$ & $6.59 \pm 0.01^{c}$ & $16.28 \pm 0.01^{\mathrm{c}}$ & $78.76 \pm 0.01^{b}$ \\
\hline & & FT & $12.32 \pm 0.01^{\mathrm{c}}$ & $7.54 \pm 0.01^{\mathrm{d}}$ & $17.68 \pm 0.01^{\mathrm{d}}$ & $78.74 \pm 0.01^{\mathrm{b}}$ \\
\hline & & RT & $15.30 \pm 0.01^{\mathrm{d}}$ & $22.12 \pm 0.01^{\mathrm{e}}$ & $22.75 \pm 0.01^{\mathrm{e}}$ & $78.47 \pm 0.03^{b}$ \\
\hline 30 & & FT & $13.66 \pm 0.01^{\mathrm{f}}$ & $12.74 \pm 0.01^{\mathrm{g}}$ & $20.15 \pm 0.00^{\mathrm{g}}$ & $78.41 \pm 0.01^{\mathrm{b}}$ \\
\hline
\end{tabular}

The color values for enzyme liquefied papaya juice $(\mathrm{PJ})$ were $\mathrm{L}=37.01 \pm 0.02 ; \mathrm{a}=9.35 \pm 0.01 ; \mathrm{b}=21.73 \pm 0.00 ; \Delta \mathrm{E}=58.64 \pm 0.01$.

\pm SD of Mean values $(n=3)$; values with same letter in a column are not significant difference at $\mathrm{p} \leq 0.05$ in Tukey-Kramer Multiple Comparisons Test.

Table 4. Storage quality of papaya juice concentrate (PJC) at various temperatures.

\begin{tabular}{|c|c|c|c|c|}
\hline \multirow{2}{*}{ Parameters } & \multirow{2}{*}{$\begin{array}{l}\text { Initial } \\
\text { (0 Day) }\end{array}$} & \multicolumn{3}{|l|}{ After 15 days } \\
\hline & & RT & $\mathbf{L T}$ & FT \\
\hline Total Soluble Solids ( ${ }^{\circ}$ brix $)$ & $68.08 \pm 0.13^{\mathrm{a}}$ & $68.20 \pm 0.03^{\mathrm{bd}}$ & $68.10 \pm 0.00^{\mathrm{ad}}$ & $68.04 \pm 0.00^{\mathrm{a}}$ \\
\hline Non-Enzymatic Browning (OD at $440 \mathrm{~nm}$ ) & $0.223 \pm 0.00^{\mathrm{a}}$ & $0.468 \pm 0.00^{\mathrm{b}}$ & $0.248 \pm 0.00^{\mathrm{c}}$ & $0.242 \pm 0.00^{\mathrm{d}}$ \\
\hline $\mathrm{pH}$ & $4.52 \pm 0.01^{\mathrm{a}}$ & $4.57 \pm 0.01^{\mathrm{b}}$ & $4.58 \pm 0.01^{\mathrm{bcd}}$ & $4.60 \pm 0.01^{\mathrm{d}}$ \\
\hline Acidity $(\%)$ & $1.76 \pm 0.01^{\mathrm{a}}$ & $1.75 \pm 0.01^{\mathrm{b}}$ & $1.75 \pm 0.00^{\mathrm{ab}}$ & $1.73 \pm 0.01^{\mathrm{b}}$ \\
\hline Viscosity (mPas) & $1065.60 \pm 0.39^{\mathrm{a}}$ & $908.88 \pm 0.20^{\mathrm{b}}$ & $922.43 \pm 0.05^{\mathrm{c}}$ & $912.96 \pm 0.13^{\mathrm{d}}$ \\
\hline Reducing sugar (\%) & $50.71 \pm 0.00^{\mathrm{a}}$ & $51.04 \pm 0.13^{\mathrm{bc}}$ & $51.02 \pm 0.17^{\mathrm{bd}}$ & $50.81 \pm 0.02^{\text {abe }}$ \\
\hline Total invert sugar (\%) & $56.67 \pm 0.01^{\mathrm{a}}$ & $56.88 \pm 0.12^{\mathrm{b}}$ & $56.78 \pm 0.01^{\mathrm{ab}}$ & $56.70 \pm 0.01^{\mathrm{a}}$ \\
\hline Total sugar $(\%)$ & $67.15 \pm 0.06^{\mathrm{a}}$ & $67.27 \pm 0.03^{b}$ & $67.17 \pm 0.03^{\mathrm{a}}$ & $67.11 \pm 0.01^{\mathrm{a}}$ \\
\hline Ascorbic acid (mg/100 g) & $12.93 \pm 0.15^{\mathrm{a}}$ & $10.48 \pm 0.01^{\mathrm{b}}$ & $10.73 \pm 0.01^{\mathrm{c}}$ & $12.54 \pm 0.02^{\mathrm{d}}$ \\
\hline Total carotenoids $(\mu \mathrm{g} / 100 \mathrm{~g})$ & $11365.53 \pm 0.50^{\mathrm{a}}$ & $11365.15 \pm 0.04^{\mathrm{b}}$ & $11365.18 \pm 0.02^{\mathrm{ab}}$ & $11365.22 \pm 0.01^{\mathrm{ab}}$ \\
\hline
\end{tabular}

Table 4. Continue.

\begin{tabular}{|c|c|c|c|c|}
\hline \multirow{2}{*}{ Parameters } & \multirow{2}{*}{$\begin{array}{l}\text { Initial } \\
\text { (0 Day) }\end{array}$} & \multicolumn{3}{|l|}{ After 30 days } \\
\hline & & RT & LT & FT \\
\hline Total Soluble Solids ( ${ }^{\circ}$ brix) & $68.08 \pm 0.13^{\mathrm{a}}$ & $68.44 \pm 0.00^{c}$ & $68.22 \pm 0.00^{\mathrm{ad}}$ & $68.19 \pm 0.01^{\mathrm{ad}}$ \\
\hline Non-Enzymatic Browning (OD at $440 \mathrm{~nm}$ ) & $0.223 \pm 0.00^{\mathrm{a}}$ & $0.515 \pm 0.00^{\mathrm{e}}$ & $0.266 \pm 0.00^{\mathrm{f}}$ & $0.261 \pm 0.00^{\mathrm{g}}$ \\
\hline $\mathrm{pH}$ & $4.52 \pm 0.01^{\mathrm{a}}$ & $4.51 \pm 0.01^{\mathrm{ae}}$ & $4.50 \pm 0.00^{\mathrm{af}}$ & $4.49 \pm 0.01^{\mathrm{def}}$ \\
\hline Acidity (\%) & $1.76 \pm 0.01^{\mathrm{a}}$ & $1.76 \pm 0.01^{\mathrm{ab}}$ & $1.76 \pm 0.00^{\mathrm{ab}}$ & $1.78 \pm 0.00^{\mathrm{a}}$ \\
\hline Viscosity (mPas) & $1065.60 \pm 0.39^{\mathrm{a}}$ & $911.39 \pm 0.02^{\mathrm{e}}$ & $958.47 \pm 0.02^{f}$ & $899.77 \pm 0.02^{\mathrm{g}}$ \\
\hline Reducing sugar (\%) & $50.71 \pm 0.00^{\mathrm{a}}$ & $51.25 \pm 0.04^{\text {cd }}$ & $51.05 \pm 0.05^{\mathrm{ce}}$ & $51.12 \pm 0.02^{\mathrm{cd}}$ \\
\hline Total sugar ( $\%)$ & $67.15 \pm 0.06^{\mathrm{a}}$ & $67.41 \pm 0.02^{\mathrm{c}}$ & $67.24 \pm 0.03^{\mathrm{ab}}$ & $67.19 \pm 0.01^{\mathrm{ab}}$ \\
\hline Ascorbic acid (mg/100 g) & $12.93 \pm 0.15^{\mathrm{a}}$ & $10.24 \pm 0.03^{\mathrm{e}}$ & $10.62 \pm 0.02^{\mathrm{bc}}$ & $12.41 \pm 0.01^{\mathrm{d}}$ \\
\hline Total carotenoids $(\mu \mathrm{g} / 100 \mathrm{~g})$ & $11365.53 \pm 0.50^{\mathrm{a}}$ & $11364.45 \pm 2.31^{\mathrm{ab}}$ & $11362.45 \pm 0.04^{\mathrm{ac}}$ & $11363.82 \pm 0.02^{\mathrm{bc}}$ \\
\hline
\end{tabular}

RT $=$ Room Temperature; LT = Low Temperature; FT = Frozen Temperature.

\pm SD of Mean values $(n=3)$; values with same letter in a row are not significant difference at $\mathrm{p} \leq 0.05$ in Tukey-Kramer Multiple Comparisons Test.

\subsubsection{Effect on Total Soluble Solids ("brix)}

The pectinase treated papaya pulp accounted for the higher levels of TSS due to enzymatic conversion of monosaccharide into sugar molecules and degradation of pectin resulted in an increase of TSS. During storage, there was marginal increase in the total soluble solids (TSS) of PJC sample; however it did not vary much as shown in Table 4 . The PJC samples stored at RT showed slightly higher TSS when compared with LT and
FT after 30 days of storage.

\subsubsection{Effect on pH and Acidity (as \% Anhydrous Citric Acid)}

The effect of storage temperature on $\mathrm{pH}$ and acidity of papaya juice concentrate is presented in Table 4. Acidity is an important parameter in food preservation. In general, the decomposition process, by hydrolysis, oxidation or fermentation, modifies the hydrogen ion concentration, and consequently food acidity [23], [24]. The titrable acidity and 
$\mathrm{pH}$ of the enzyme liquefied papaya juice (PJ) were slightly more as compared to fresh papaya pulp which may be due to the enzymatic de-esterification and degradation of pectin, and the release of carboxyl groups from the pectin molecules result in an increase of titrable acidity. Similar results were reported earlier by [25] while working on enzymatic liquefaction of mango pulp. Initially, the titrable acidity of the PJC was found to be more as compared to papaya juice, which may be due to concentration process by which water is removed and total solids are concentrated under vacuum. The quality of the PJC samples were found good during storage at RT, LT \& FT but slight changes in $\mathrm{pH}$ and acidity were observed throughout the storage periods (30 days).

\subsubsection{Effect on Viscosity}

Papaya juice showed different trend in viscosity while comparing with PJC. It was observed that as the concentration increases, the flow shows the Non-Newtonian behavior while at lower concentration, the papaya juice tends to Newtonian behavior. The increase in viscosity of PJC (1066 mPas) as compared to papaya juice $(12.70 \mathrm{mPas})$ is attributed to the high degree brix of the concentrate and also the residual pectin, which remains even after enzymatic liquefaction (Table 2). Initially, viscosity of the PJC sample was found to be more, but it behaved differently according to storage at varying temperatures (significantly different at $\mathrm{p} \leq 0.05$ ) throughout storage time (Table 4), which was totally temperature dependent. It has been reported earlier that the viscosity decreased with the increasing shear rates for fruit juices with varying concentrations that can be explained by the structural breakdown of the blend due to the hydrodynamic forces generated and the increased alignment of the constituent molecules e.g. sugar and protein [14], [26], [27], [28].

\subsubsection{Effect on Total Carotenoids}

A slight loss of total carotenoids was observed during storage of PJC at various temperatures (Table 4). Although a slightly higher content of carotenoids was observed in 15 days stored samples as compared to 30 days stored samples, the overall variations were less in total carotenoids. FT stored PJC samples have shown slightly higher retention of total carotenoids as compared to LT and RT stored samples after 15 days storage but trend was reversed in 30 days stored PJC samples and RT stored PJC samples have shown slightly higher retention of total carotenoids followed by FT \& LT stored samples. Earlier studies also suggest that carotenoids are relatively stable during storage at room temperature and below [29]. Freezing is the most efficient way to prevent loss of carotenes for long-term storage in food products. Previous studies revealed that the frozen storage of mangoes and kiwi fruits have resulted in good retention of carotenoid [30], [31]. The retention of carotenes can be improved by storage at low temperature, low light, and low water content [32].

\subsubsection{Effect on Sugars (Reducing Sugar, Total Invert Sugar and Total Sugar)}

The contents of total sugars as well as reducing sugars were elevated in the PJC when compared with fresh papaya juice (significantly different at $\mathrm{p} \leq 0.05$ ). The sugar content in the enzyme liquefied papaya juice (PJ) increased significantly due to the complete hydrolysis of macromolecules. Hence, the fruit juice prepared from enzymatic liquefaction has different flavor and composition compared to mechanically pressed juice as reported earlier by [33]. The increase in sugars in PJC sample is due to the concentration process in which water is removed by evaporation process under vacuum. The changes in reducing sugar, total invert sugar and total sugar are shown in Table 4. The slight increase in the reducing sugar, total invert sugar and total sugar of the PJC samples stored at RT, LT and FT were observed throughout the storage period, which might be due the influence of storage temperatures. During storage of PJC samples at RT, LT and FT, the sucrose might have hydrolyzed so the reducing sugars increased and it mainly depends on the inversion of sucrose in presence of citric acid or any other organic acid.

\subsubsection{Effect on Ascorbic Acid}

The influence of storage conditions on the ascorbic acid content is presented in the Table 4 . The gradual decrease in the ascorbic acid throughout the storage period was noticed (significantly different at $\mathrm{p} \leq 0.05$ ). The results revealed that the ascorbic acid content was retained more in FT (95.97\%) as compared to LT (82.13\%) stored PJC samples and least retention of ascorbic acid was observed in RT (79.19\%) stored PJC sample at the end of storage period (30 days). It could be due to the influence of temperatures which indicates that the FT and LT have a better preserving effect on the retention of ascorbic acid. Ascorbic acid stability in fruit processing depends on several factors like $\mathrm{pH}$, oxygen availability and also the presence of catalysts. In other words, ascorbic acid degradation could be possible due to light and enzymatic activity to which product is exposed [34], [35], [36], [5]. The oxygen, which is present in the head space of the packed product might have dissolved in the juice or juice concentrate, can cause ascorbic acid degradation. The other factor for the degradation of ascorbic acid is the influence of temperature exerted at the time of processing and also the storage temperature of product.

\subsubsection{Effect on Microbial Stability of PJC}

The microbial stability of the enzyme liquefied papaya juice and stored papaya concentrate at varying temperature were studied at regular intervals (Table 5). Microbial load plays a very important role in determination of the length of storage till which the product remains consumable. The microbial quality of both juice and concentrate was found to be good as the total plate count was much below the standard limits for fruit and vegetable product of $40000 \mathrm{cfu} / \mathrm{g}$ [37]. Similarly, yeast and molds counts were also very low, although Staphylococcus was present after 15 days storage and at the end of the 30 days storage, the count was very low $(<10 \mathrm{cfu} / \mathrm{g})$. $E$. coli was not detected in any of the storage conditions, indicating that product was free of pathogenic bacteria. The microbial analysis showed that product is safe for consumption after 30 days of storage. High degree brix concentrates prepared under vacuum at specific temperature 
might have controlled the microbial growth due to the action of the high osmotic pressure, temperature and lower water activity [38], [39]. There is a possibility of high mold or bacteria counts in the fruit juice concentrate if the equipment used for evaporation process is poorly cleaned. The high count for yeast or lactic acid bacteria is indicative of fermentation of the product [16] but in our studies, the PJC samples showed all the counts within the permissible limits irrespective of their storage conditions, which indicate microbiological stability of the product.

Table 5. Microbial Analysis of enzyme liquefied papaya juice (PJ) and papaya juice concentrate (PJC) stored at various temperatures (RT, LT and FT).

\begin{tabular}{|c|c|c|c|c|c|c|}
\hline $\begin{array}{l}\text { Storage } \\
\text { (in days) }\end{array}$ & Sample & $\begin{array}{l}\text { Storage } \\
\text { Temperature }\end{array}$ & $\begin{array}{l}\text { Total Plate Count } \\
\text { (cfu/g) }\end{array}$ & $\begin{array}{l}\text { Yeast and Molds } \\
\text { count (cfu/g) }\end{array}$ & $\begin{array}{l}\text { Staphylococcus count } \\
(\mathrm{cfu} / \mathrm{g})\end{array}$ & $\begin{array}{l}\text { E. coli detection } \\
(\mathrm{cfu} / \mathrm{g})\end{array}$ \\
\hline \multirow{2}{*}{0} & PJ & --- & 18 & $<10$ & $<10$ & ND \\
\hline & PJC & --- & 310 & $<10$ & $<10$ & ND \\
\hline \multirow{3}{*}{15} & \multirow{3}{*}{ PJC } & RT & 732 & $<10$ & 06 & ND \\
\hline & & LT & 486 & $<10$ & 06 & ND \\
\hline & & FT & 489 & $<10$ & 03 & ND \\
\hline \multirow{2}{*}{30} & \multirow{2}{*}{ PJC } & RT & 525 & $<10$ & $<10$ & ND \\
\hline & & FT & 301 & $<10$ & $<10$ & ND \\
\hline
\end{tabular}

Mean values ( $\mathrm{n}=3) ; \mathrm{ND}=$ Not detected in $25 \mathrm{~g}$ sample;

$\mathrm{RT}=$ Room Temperature; LT $=$ Low Temperature; FT $=$ Frozen Temperature.

\section{Conclusions}

The present study showed that enzymatic liquefaction can be used for better juice extraction from papaya and it can be followed for other fruits and vegetables where juice extraction is problematic. This study showed that the enzymatic liquefaction of papaya pulp is the best alternative to facilitate smooth juice extraction with high yield and also for concentration of papaya juice to a higher degree brix juice concentrate. Storage studies of PJC revealed that the product was microbiologically safe for consumption and all the physicochemical characteristics were retained after 30 days storage. The FT and LT temperatures have shown better quality retention of PJC as compared to RT in terms of low non-enzymatic browning and higher ascorbic acid content. Although we found the quality of stored product remains unaltered for one month, a longer storage study will be required for potential utilization of this technique.

\section{Acknowledgements}

Authors thank Director, CSIR-Central Food Technological Research Institute, Mysore for encouragement and Central Instrumentations Facility and Services (CIFS) Department for technical support pertaining to instrumentation.

\section{References}

[1] Rai, P., Majumdar, G.C., Das Gupta, S., \& De, S. (2004). Optimizing Pectinase usage in pre-treatment of mosambi juice for clarification by response surface methodology. Journal of Food Engineering, 64, 397 - 403.

[2] Rastogi, N.K. \& Rashmi, K.R. (1999). Optimization of enzymatic liquefaction of mango pulp by response surface methodology. European Food Research and Technology, 209, 57-62.

[3] Sreenath, H.K., \& Santharam, K. (1992). The use of commercial enzymes in white grape juice clarification. Journal of Fermentation and Bioengineering, 2, 241 - 243.

[4] Pilnik, W., \& Voragen A.G.J. (1989). Effect of enzyme treatment on the quality of processed fruits and vegetables. In: Jen, J.J. (Ed), Quality factors of fruits and vegetable chemistry and technology, pp 250-269, Symposium Series 405, American Chemical Society, Washington DC.

[5] Chauhan, A.S., Afroze, S.G., Ramesh, M.N., Avula, R.Y., Rekha, M.N., \& Ramteke, R.S. (2004). Optimization of enzymatic liquefaction of papaya and jackfruit pulp using response surface methodology. Journal of Food Agriculture and Environment, 2 (2), 108-113.

[6] Vasserot, Y., Christiaens, H., Chemardin, P., Arnaud, A., \& Galzy, P. (1989). Purification and properties of a ß-glucosidase of Hunseniosporu vime (Van der Walt and Tscheuschner) with the view to its utilization in fruit aroma liberation. Journal of Applied Bacteriology, 66 (4), 271-279.

[7] Manjunatha, S.S., Raju, P.S., \& Bawa, A.S. (2012). Modelling the rheological behaviour of enzyme clarified lime (Citrus aurantifolia L.) juice concentrate. Czech Journal of Food Science, 30, 456-466.

[8] Vijayanand, P., Kulkarni, S.G., \& Prathibha, G.V. (2010). Effect of pectinase treatment and concentration of litchi juice on quality characteristics of litchi juice. Journal of Food Science and Technology, 47 (2), 235-239.

[9] Sharma, S.K., Sharma, P.C., \& Lal Kaushal, B.B. (2001). Effect of storage temperature and folds of concentration on quality characteristics of galgal (Citrus pseudolimon Tan.) juice concentrates. Journal of Food Science and Technology, 38 (6), 553-556.

[10] Abduljalil, D.S.G., Ronald, E.W., \& Mina, R.M. (2002). Composition and quality of clarified cantaaoupe juice concentrate. Journal of Food Processing and Preservation, 26 (1), 39-56.

[11] Wrolstad, R.E., Cornwell, C.J., Culbertson, J.D., \& Reyes, F.G.R. (1981). Establishing criteria for determining the authenticity of fruit juice concentrates. In: Teranishi R, Barrera-Benitez H (Eds). Quality of selected fruits and vegetables of North America. ACS-Symposium-Series, 170, American Chemical Society, Washington DC, pp 77-93. 
[12] Kulkarni, S.G., Vijyayanand, P., \& Shubha, L. (2010). Effect of processing of dates into date juice concentrate and appraisal of its quality characteristics. Journal of Food Science and Technology, 47 (2), 157-161.

[13] Belibagli, K.B., Dalgic, A.C. (2007). Rheological properties of sour-cherry juice and concentrate. International Journal of Food Science and Technology, 42, 773-776.

[14] Keshani, S., Luqman Chuah, A., \& Russly, A.R. (2012). Effect of temperature and concentration on rheological properties pomelo juice concentrates. International Food Research Journal, 19 (2), 553-562.

[15] Ramteke, R.S., Singh, N.I., Rekha, M.N., \& Eipeson, W.E. (1993). Methods for Concentration of Fruit Juices: A Critical Evaluation. Journal of Food Science and Technology, 30, 391-402.

[16] Neha, I.B., \& Tumane, P.M. (2011). Studies on microbial flora of fruit juices and cold drinks. Asiatic Journal of Biotechnology Resources, 2 (4), 454-460.

[17] Ranganna, S. (2002). Handbook of analysis and quality control for fruit and vegetable products. In: Ranganna, S. (Ed), Tata Mc-Graw Hill publishing Co. Ltd, New Delhi.

[18] Vanderzant, C., \& Splittstoesser, D. (1992). Compendium of methods for the microbial examination of foods. In: Vanderzant C, Splittstoesser D (Eds), $3^{\text {rd }}$ Edn, APHA, Washington DC.

[19] Aider, M., Halleux, Dde., \& Belkacemi, K. (2007). Production of granulated sugar from maple syrup with high content of inverted sugar. Journal of Food Engineering, 80, 791-797.

[20] Martins, S.I.F.S., Jongen, W.M.F., Van Boekel, M.A.J.S. (2001) A review of Maillard reaction in food and implications to kinetic modeling. Trends in Food Science and Technology, 11, 364-373.

[21] Wong, M., \& Stanton, D.W. (1989). Nonenzymic browning in kiwifruit juice concentrate systems during storage. Journal of Food Science, 54 (3), 669-673.

[22] Hande, S.B., \& Feryal, K. (2003). Effect of storage on non-enzymatic browning of apple juice concentrates. Food Chemistry, 80, 91-97.

[23] Pereira, C.D.Q., Lavinas, F.C., Lopes, M.L.M., \& Valente-Mesquita, V.L. (2008). Industrialized cashew juices: variation of ascorbic acid and other physicochemical parameters. Ciência e Tecnologia de Alimentos Campinas, 28, 266-270.

[24] IAL. (1985). Normas Analíticas: Métodos Químicos e Físicos para Análise de Alimentos, $3^{\text {rd }}$ ed., Instituto Adolfo Lutz, São Paulo.

[25] Singh, N.I., Mayer, C.D., Lozano, Y. (2000). Physicochemical changes during enzymatic liquefaction of mango pulp (cv. Keit). Journal of Food Processing and Preservation, 24, 73-85.
[26] Arslan, E., Yener, M.E., \& Esin, A. (2005). Rheological characterization of tahin/pekmez (sesame paste/concentrated grape juice) blends. Journal of Food Engineering, 69, 167-172.

[27] Rao, M.A. (1999a). Introduction. In: Rao, M.A. (Ed), Rheology of fluid and semisolid foods: Principles and Applications, Aspen Publishers Inc, Gaithersburg, Maryland, USA, pp 1-22.

[28] Rao, M.A. (1999b). Flow and functional models for rheological properties of fluid foods. In: Rao, M.A. (Ed), Rheology of fluid and semisolid foods: Principles and Applications. Aspen Publishers Inc, Gaithersburg, Maryland, USA, pp 25-59.

[29] Namitha, K.K., \& Negi, P.S. (2010). Chemistry and biotechnology of carotenoids. Critical Reviews in Food Science and Nutrition, 50, 728-760.

[30] Cano, M.P., De Ancos, B. (1994). Carotenoid and carotenoid ester composition of mango fruit as influenced by processing method. Journal of Agricultural and Food Chemistry, 42, $2737-2742$.

[31] Cano, M.P., \& Marin, M.A. (1992). Pigment composition and color of frozen and canned kiwi fruit slices. Journal of Agricultural and Food Chemistry, 40, 2141-2146.

[32] Shi, J., \& Le Maguer, M. (2000). Lycopene in tomatoes: chemical and physical properties affected by food processing. Critical Reviews in Biotechnology, 20, 293-334.

[33] McLellan, M.R., \& Padilla-Zakour, O.I. (2005). Juice processing. In: Barrett, D.M., Somogyi, L.P., \& Ramaswamy, H. (Eds), Processing Fruits: Science and Technology, CRC Press, Boca Raton, pp 72-95.

[34] Klein, B.P. (1987). Nutritional consequences of minimal processing of fruits and vegetables. Journal of Food Quality, 10, 179-193.

[35] Tovar, B., Garcie, H., \& Mata, M. (2001). Physiology of pre-cut mango II. evolution of organic acids. Food Research International, 34, 705-714.

[36] Rincon, A., \& Kerr, W.L. (2010). Influence of osmotic dehydration, ripeness and frozen storage on physicochemical properties of mango. Journal of Food Processing and Preservation, 34 (5), 887-903.

[37] FSSAI. (2011). Food Safety and Standards Authority of India Food Safety and Standards (Food Product Standards and Food Additives) regulation, (Part II), pp 496-503.

[38] Frazier \& Westhoff (1978). Food Microbiology, $3^{\text {rd }}$ Ed. Tata McGraw Hill.

[39] Phaichamnan, M., Posri, W., \& Meenune, M. (2010). Quality profile of palm sugar concentrate produced in Songkhla province, Thailand. International Food Research Journal, 17, 425-432. 